\title{
Isolation of bacteriophages from untreated sewage water against multi-drug resistant E.coli - An initiative to fight against drug resistance
}

Hina Qamar ( $\square$ hina.dna@rediffmail.com )

Chaudhary Charan Singh University

\section{Mohd Owais}

Interdisciplinary Biotechnology Unit, Aligarh Muslim University, Aligarh

Dushyant Kumar Chauhan

Chaudhary Charan Singh University, Meerut

\section{Sumbul Rehman}

Aligarh Muslim University, Aligarh

Research article

Keywords: Multi-drug resistance, bacteriophage, sewage, phage titer, E.coli

Posted Date: May 6th, 2019

DOI: https://doi.org/10.21203/rs.2.9474/v1

License: (a) (i) This work is licensed under a Creative Commons Attribution 4.0 International License.

Read Full License 


\section{Abstract}

Background: Pathogenic Escherichia coli, common drinking water contaminant, cause a large number of morbidity and mortality worldwide. According to the WHO estimates approximately 63,000 annual deaths are due to E. coli infections. Due to selective pressure on coliforms, resistant microbial strains are produced that threatens modern medicine where common infections could become more deadly. So, there is an urgent need to develop alternative anti-microbial to replace existing antibiotics for treating a broad spectrum of bacterial diseases. This revived the interest of scientists in phages as an alternative therapy. Phage therapy is defined as a therapeutic use of bacteriophages (natural predators of bacteria) for treating bacterial infections. In the present study pure phage strain was isolated from the untreated sewage water sample and subjected to 10 fold dilution following double agar layer assay to determine phage titer against multi-drug resistant E.coli following host range analysis and stability testing at varying temperature and $\mathrm{pH}$. Results: Sewage water contains a vast variety of different sizes bacteriophages with clear to diffused boundaries. The pure plaque isolated after repeated plating showed that it was highly specific against tested $\mathrm{E}$. coli strain and could not lyse strains from other species. The titer was calculated to be $109 \mathrm{PFU} / \mathrm{ml}$ that remained unchanged at $4^{\circ} \mathrm{C}, 37^{\circ} \mathrm{C}$ and $50^{\circ} \mathrm{C}$ temperature. However, at higher $\mathrm{pH}$ range phage viability decreases. Conclusions: In future, it would be expected that the isolated bacteriophages could be characterized and used as a therapeutic potential against multidrug resistant E.coli that not only attenuate superbug spread but could also replace antibiotics. Beside, isolated phages would be utilized as a bio-component in biosensor development against food borne pathogenic bacteria.

\section{Background}

Pathogenic Escherichia coli (E. coli), is a common fecal coliform (facultative aerobic Gram negative rods) bacterium. It is a common drinking water contaminant that causes a large number of morbidity and mortality worldwide. According to the WHO estimates approximately 63,000 annual deaths are due to $E$. coli infections [1]. Beside gastrointestinal tract infections, $E$. coli is responsible for $8.9 \%$ of sepsis cases, $29 \%$ of early onset neonatal sepsis cases and the majority of urinary tract infections [2]. Because these organisms are naturally found in human feces in high concentrations, so when the fecal matter gets disposed off and reaches drainage systems where already overused or misused antibiotics released from clinical aspects and agricultural run-offs prevail create pressure on coliforms and produce resistant microbial strains. The persistence of antibiotic resistant microbes not only creates selective pressure on nearby exposed bacteria but also increases opportunities to transfer the resistance genes to associated susceptible bacteria (via horizontal gene transfer involving plasmids, transposons or integrons) that eventually lead to entry into the human food chain [3-4]. This allows them to survive beyond the inhibition or toxicity thresholds. Thus, focuses our interest to develop such anti-microbial that could fight against such situations.

In the present scenario there is an urgent need to develop alternative anti-microbial to replace antibiotics for treating a broad spectrum of bacterial diseases. Action is needed due to an alarming increase of 
antibiotic resistance that threatens modern medicine where common infections could become more deadly. WHO releases a list of 12 most dangerous superbugs that pose health hazards, E.coli is among one of them [5]. Though worldwide several researchers are working out to fight against it by creating new drugs and other alternatives yet unable to root out the problem. This revived the interest of scientists in phages as an alternative therapy. Phage therapy is defined as a therapeutic use of bacteriophages (natural predators of bacteria) for treating bacterial infections [6]. Beside, phages are the most "safe" and "green" entities applicable for clinical application. Apart from self replication and ability to kill antibioticresistant bacteria they are ubiquitous in nature and have high specificity that leads to minimal disruption to normal flora [7]. Unlike antibiotics, whose concentration decreases with time after dosage, phages continuously replicate and infect the target bacteria [8]. The resistance to phages is not transferrable when compared to antibiotics. Also, the isolation of a new phage is relatively fast and cheap compared to the discovery of a new antibiotic. Phage therapy or use of bacteriophages as therapeutic agents for eradicating bacterial infections was first introduced by preliminary studies of Twort and D'Herelle in the beginning of the 20th century [9-10]. Keeping this in view, present investigation was carried out to isolate pure phage strain against multi-drug resistant $E$. coli from untreated sewage water.

\section{Results}

Antimicrobial susceptibility testing: The strain was tested against 11 antibiotics and was found to be resistant to five antibiotics which were generally $\beta$ - lactam and cephalosporin antibiotics (Table1).

Preliminary screening of bacteriophages: In order to confirm the presence of bacteriophages in the sample, preliminary screening using turbidity reduction and streak plate techniques was done. OD of the sample was recorded as 1.9 with respect to control that was 2.7 at $600 \mathrm{~nm}$ wavelength. As OD of sample decreases when compared to control suggest that bacteriophages present in the sample lyse the bacteria that result in reduction in the bacterial growth and thus turbidity gets reduced. Next, in streak plate technique when $100 \mu$ l phage lysate was inoculated over the surface of E.colibacterial lawn on LB agar plates clear regions over the surface of E.coli bacterial lawn on LB agar plates were observed which suggest that sample contains bacteriophages.

Characteristics of bacteriophages present in the sewage: After 48 hours of incubation, each plate was carefully observed for visible plaques. On each plates non uniform several different plaques were formed that were not clearly discernible from each other (more than 300 plaques) and recorded as TNTC (too numerous to count) (Fig. 1). By drawing 8 grids on some plates approximate number of plaques were counted and found to be in the range of 280- 1200 (Fig. 2).

To calculate the phage titer of sample less populated plate with 30 to 300 countable plaques was chosen and the number of phage in a solution was determined by calculating the number of plaque forming units per milliliter of phage (PFU/ml) by applying the following formula:

PFU per $\mathrm{ml}=($ Plaques per plate $) \times$ (dilution factor) $/$ (Volume of phage plated in $\mathrm{ml})$ 
The phage titer of the sample was calculated to be within the range of $102-107 \mathrm{PFU} / \mathrm{ml}$ (Table 2).

On the basis of morphology, 5 different lytic bacteriophages were isolated against E.coli. Morphology of plaque was recorded in terms of size, edge, and boundaries and was noted as small ( $<1 \mathrm{~mm}$ ), medium $(=1 \mathrm{~mm})$, and large $(>1 \mathrm{~mm})$ with clear or diffused type plaques. From each plate, number of plaques were recorded and counted as described earlier (Table 3 ).

Isolation of pure phage and determination of phage titers: In order to isolate a single phage strain one of the plate carrying 11 plaques was subjected to repeated plating and each time 10 fold dilution was carried following 20-200 plaques for the next step. After repeating the process 5 times uniform plaques of round shaped clear regions of $<1 \mathrm{~mm}$ size get clearly visible. To isolate pure phage strain again one of the plaques was picked from the plate having uniform phages and subjected to enrichment followed by DAL. This process was repeated three times (Fig.3). Lastly, 10 fold dilutions were carried out in order to determine the phage titer of pure phage strain. The phage titer for an isolated single phage strain was found to be 6 X109 PFU/ml (Table 4).

Host range determination of isolated pure plaque: In this study, the host range of the isolated pure phage when tested against 7 different gram positive and gram negative bacterial strains (namely, Staphylococcus aureus, Streptococcus viridans, Streptococcus mutans, Corynebacterium xerosis, Bacillus cereus, Proteus vulgaris and Pseudomonas aeruginosa) revealed negative results but for ATCC 25922 E.coli strain showed positive results. This suggested that the phage isolated was highly specific.

Isolated pure plaque stability assessment: The thermal and $\mathrm{pH}$ tolerance of pure isolated phage was analyzed at different conditions. The phage when treated at $4{ }^{\circ} \mathrm{C}, 37^{\circ} \mathrm{C}$ and $50^{\circ} \mathrm{C}$ showed no significant decrease in phage viability thus, are tolerant to these temperatures. But phage showed high resistance against $\mathrm{pH}$ treatment. The phage was stable when treated at $\mathrm{pH}$ between 3 and 7 , while treating the phage with $\mathrm{pH} 9$, result in decreased plaques per plate and with $\mathrm{pH} 11$ a drastic decrease in plaques occurred (Table 5).

\section{Discussion}

Extensive antibiotics use for human and veterinary concern, exhibits resistance against many antimicrobial drugs. Previous studies have reported several MDR E.coli strains that exhibit resistance through several mechanisms such as the production of extended spectrum $\beta$-lactamases and carbapenemase. Our study showed that the $E$. coli isolated from clinical sample was resistant to several $\beta$-lactam antibiotics that were in accordance with the several studies reported by authors from different parts of the India [11-15]. These E.coli MDR strains not only causes severe infection in humans but also make it difficult to control by using antibiotics. So, Phage therapy using bacteriophage as biocontrol agents is an effective alternative treatment option against multiple drug-resistant pathogens. According to the ICTV classification of bacteriophages include 982 different types in Enterobacteriaceae, among which 265 phages belong to Podoviridae, 297 phages to Siphoviridae and 344 phages to Myoviridae [16]. In the present study, lytic bacteriophage against E.coli was isolated from a sewage water sample and 
phage titer was determined. Turbidity reduction and streak plate methods were used as preliminary screening methods [17] with subsequent processing by DAL method with slight modifications. The protocol used during the study is so simple and easy that it could be used to reproduce best results for the future use. On the basis of morphology, five different lytic bacteriophages were isolated that were in accordance with the previous studies reported and the titer was calculated to be within the range of 102 $109 \mathrm{PFU} / \mathrm{ml}$. The previous study reported phage titer of $2.15 \times 109 / \mathrm{ml}$ at a dilution of $10-7$ [18]. The pure phage isolated when exposed to different host range only form plaques against ATCC 25922 E. coli strain suggesting highly specific characteristic that was in accordance with several findings reported earlier [1920]. To determine stability of phage under different conditions percent viability with respect to control was analyzed. Activity of phages was found to remain stable at different temperature suggesting thermal tolerance while vary with $\mathrm{pH}$ [21].

Earlier studies reported bacteriophages use for the removal of bacterial pathogens such as $E$. coli in hospital wastewater. The study showed that the specific phages of $E$. coli destroyed the bacterial host after 14 hours of incubation [22].

\section{Conclusions}

It was concluded that the phages isolated in the experiment were all lytic as they form clear zones of lysis against host bacterium. Lytic bacteriophage isolated against multi-drug resistant $E$.coli might be used as potential therapeutic alternatives to antibiotics both in humans and animals after further study. This could be because widespread use of antibiotics for clinical, veterinary, animal or agriculture purpose has made antibiotics less and less effective which results in emergence of bacterial resistance to antibiotics. In future, it would be expected that the isolated bacteriophages could be used as a therapeutic potential against multi-drug resistant $E$.coli that not only attenuate superbug spread but could also replace antibiotics. Beside, isolated phages would be utilized as a bio-component in biosensor development against food borne pathogenic bacteria.

\section{Methods}

Bacterial strain, growth media and culture conditions: Clinically isolated Escherichia coli strain (a kind gift from Jawaharlal Nehru Medical College, AMU, Aligarh) was used for the isolation and propagation of bacteriophages. The E.coli culture was cultivated in Luria Bertani agar (Hi-Media, India) and Luria Bertani broth (Hi-Media, India) and incubated at 37oC.

Preparation of LB agar for topping: $0.75 \%$ LB agar (Hi Media laboratories Pvt. Ltd.) was used for topping.

Antimicrobial susceptibility testing: Antimicrobial susceptibility testing of the E.coli clinical strain was determined using Kirby-Bauer disk diffusion method according to the Clinical and Laboratory Standards

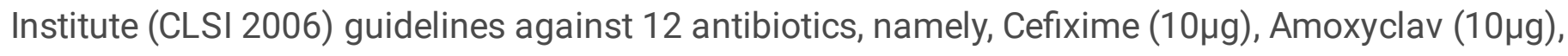
Amikacin $(10 \mu \mathrm{g})$, Azithromycin $(10 \mu \mathrm{g})$, Ofloxacin $(10 \mu \mathrm{g})$, Streptomycin $(10 \mu \mathrm{g})$, Fusidic acid $(10 \mu \mathrm{g})$, Norfloxacin $(10 \mu \mathrm{g})$, Tetracycline $(10 \mu \mathrm{g})$, Cefotaxime $(10 \mu \mathrm{g})$, Methicillin $(10 \mu \mathrm{g})$, and Ampicillin $(10 \mu \mathrm{g})$ and 
plates were incubated at $37^{\circ} \mathrm{C}$ for 24 hours. Next day, the diameters of the zone of inhibition around the discs were measured [23-24].

Collection and processing of sewage water samples: Untreated sewage water sample from one of the drainage system of Aligarh district was collected in sufficient amount in sterilized tubes from the top strata of running sewage water, brought to the lab and stored overnight at room temperature to settle any large debris and insoluble waste. Next day, the clear supernatant was collected and tested (as mentioned below) for the presence of bacteriophage against multi-drug resistant $E$. coli.

Amplification, isolation and preliminary screening of bacteriophages: Untreated sewage water sample was used for isolation of active phages by culture-enrichment method according to the Sambrook et.al, 1989 protocol with slight modifications [25]. Briefly, $5 \mathrm{ml}$ of Luria Bertani broth (LB broth) was mixed with $40 \mathrm{ml}$ of sewage water and $5 \mathrm{ml}$ of an overnight culture of log phase $E$. coli in $250 \mathrm{ml}$ flask. The mixture was incubated at $37^{\circ} \mathrm{C}$ in a shaking incubator at $200 \mathrm{rpm}$ for 24 hours. Sewage-bacteria bacteriophage culture was then centrifuged at 5,000 rpm for 15 minutes. Supernatant (containing bacteriophages) was collected and filtered through 0.22 micron filter and filtrate (i.e., phage lysate) was stored at $4^{\circ} \mathrm{C}$ for further use. To check the presence of phages in filtrate parallel turbidity reduction and streak plate technique were used as preliminary methods for screening of lytic activity of phages following the protocol of Shende et.al, 2017 with slight modifications [26]. Briefly, in turbidity reduction method, OD of enriched culture is measured at $600 \mathrm{~nm}$ wavelength with respect to control while in strike plate method, $100 \mu \mathrm{l}$ phage lysate was inoculated over the surface of E.coli bacterial lawn on LB agar plates. Next day, plates were examined for the presence of visible plaques or any lytic activity on bacterial lawn.

Isolation, characteristics and determination of phage titers: The presence of any phages in the enriched filtrate was carried out by more sensitive double agar layer (DAL) method [27-28] with slight modifications. Briefly, lysate was serially diluted I0-fold with PBS (Phosphate Buffer Saline). From each dilutions $100 \mu$ l lysate was mixed with $100 \mu$ l of log-phase $E$. coli and left for 10 minutes at $4^{\circ} \mathrm{C}$ so that phage adsorb to the host. Then, added $3000 \mu \mathrm{l}$ molten soft agar (molten, at $45^{\circ} \mathrm{C}$ in a water bath, Agar$0.7 \%)$ to the cell-phage mix and gently mixed and poured onto LB agar plates. The plates were incubated for 48 hours at $370 \mathrm{C}$ and dilutions showing countable plaques with different morphology were counted. Morphology of plaque was recorded in terms of size, edge, and boundaries and was noted as small (under $1 \mathrm{~mm}$ ), medium (1 mm), and large (larger than $1 \mathrm{~mm}$ )/clear or diffused type plaques [26]. Subsequently, individual phage of single strain was purified by repeatedly plating and picking individual plaques. Briefly, one of the visible plaque from culture plate was picked along with the surrounding cell mass using sterile pipette tip by piercing the agar surrounding the plaque, and picking out the agar plug containing the plaque. Transferred the picked plaque to culture vial containing $5 \mathrm{ml}$ of LB broth and $2 \mathrm{ml}$ log phase E.coli and incubated at $37^{\circ} \mathrm{C}$ for 48 hours for enrichment. Transferred the culture vial content into centrifuge tube, and centrifuged the sample at $5000 \mathrm{rpm}$ for 15 minutes. Collected the supernatant and filtered the collected supernatant with 0.22 micron filter. Next, to $900 \mu \mathrm{l}$ PBS added $100 \mu \mathrm{l}$ phage suspensions and stored till further use. Now performed DAL and counted the plaques. To isolate uniform plaques of single phage strain the process was repeated 5 times. Finally, single phages isolated were 
subjected to 10 fold serial dilution ten times for determining phage titration in the form of plaque-forming units (PFU/ml) [29].

Host range determination of isolated pure plaque: To determine the host range of pure isolated phage, ATCC 25922 E. colistrain along with different MDR bacterial strains were tested (namely, Staphylococcus aureus, Streptococcus viridans, Streptococcus mutans, Bacillus cereus, Proteus vulgaris, Pseudomonas aeruginosa and Corynebacterium xerosis ) using standard spot test [30]. Each test strain was grown separately overnight in LB broth and $100 \mu \mathrm{L}$ of the strain was mixed with $5 \mathrm{ml}$ melt semisolid medium to pour the double-layer medium. Then, $10 \mu \mathrm{L}$ purified phage suspension (approximately $107 \mathrm{PFU} / \mathrm{ml}$ ) was spotted onto the upper layer medium against each strain and left to incubate overnight. Bacterial sensitivity to phage occurred with the formation of the spot where the phage suspension was deposited. The experiment is repeated three times at $37^{\circ} \mathrm{C}$.

Isolated pure plaque stability assessment: The stability of isolated pure bacteriophage at different conditions of temperature and $\mathrm{pH}$ was determined $[21,30]$. To ascertain the stability of bacteriophages at different temperatures, $107 \mathrm{PFU} / \mathrm{ml}$ titer of phage lysate was assayed after storage at $4^{\circ} \mathrm{C}, 37^{\circ} \mathrm{C}$ and $50^{\circ} \mathrm{C}$ for 24-48 hrs [31] by the double agar layer method. Similarly, phage stability at different $\mathrm{pH}$ was evaluated by incubating the phages in PBS buffers of different $\mathrm{pH}$, ranging from 2-11 following doublelayer agar plate method.

\section{Abbreviations}

DAL: Double Agar Layer; ICTV: International Committee for Taxonomy of Viruses; LB: Luria Bertani; MDR: Multi-Drug Resistant; OD: Optical Density; PBS: Phosphate Buffer Saline; PFU: Plaque Forming Unit; WHO: World Health Organization.

\section{Declarations}

Ethics approval and consent to participate: Not applicable.

Consent for publication: Not applicable.

Availability of data and material: All data generated or analyzed during this study are included in this published article.

Competing interests: The authors declare that they have no competing interests.

Funding: The work was supported by Interdisciplinary Biotechnology Unit, Aligarh Muslim University, Aligarh and Department of Zoology, Chaudhary Charan Singh University, Meerut. The work was done in collaboration between the two institutes. The financial and material support for this work was provided by both institutes under DRS program. The funding agency had no role in experiment design, sample collection, data analysis and interpretation and in writing of this manuscript. 
Author's contributions: $\mathrm{HQ}$ and $\mathrm{MO}$ conceived and designed the experiments; $\mathrm{HQ}$ performed the experiments and analyzed the data; HQ, MO, DKC and SR supported and wrote the paper. All authors read and approved the final manuscript.

Acknowledgements: We thank Prof. S.S.Lal of Zoology Department, CCSU, Meerut and Dr. Touseef Hussain of Botany Department AMU, Aligarh for their valuable comments on the manuscript and kind support.

\section{References}

1. WHO estimates of the global burden of food borne diseases 2007-2015 report.

2. Barantsevich E. et al. Etiological agents of bacterial sepsis in a newly constructed medical center in Saint Petersburg, Russia. Critical Care. 2011; 15:45-45.

3. Bouki C, Venieri D, Diamadopoulos E. Detection and fate of antibiotic resistant bacteria in wastewater treatment plants: A review. Ecotoxicol. Environ. Saf. 2013; 91:1-9.

4. Sharma VK, Johnson N, Cizmas L, Mc Donald TJ, Kim H. A review of the influence of treatment strategies on antibiotic resistant bacteria and antibiotic resistance genes. Chemosphere. 2016; 150:702714.

5. www.who.int/medicines/publications/WHO-PPL-Short_Summary_25Feb ET_NM_WHO. pdf.

6. Viertel TM, Ritter K, Horz H.P. Viruses versus bacteriophage novel approaches to phage therapy as a tool against multidrug-resistant pathogens. J. Antimicrob. Chemother. 2014; 69(9):2326-2336.

7. Koskella B, Meaden S. Understanding bacteriophage specificity in natural microbial communities. Viruses. 2013; 5(3):806-823.

8. Kutateladze M, Adamia R. Bacteriophages as potential new therapeutics to replace or supplement antibiotics. Trends Biotechnol. 2010; 28(12):591-595.

9. Marks T, Sharp R. Bacteriophages and biotechnology: A review. J Chem Technol Biotechnol. 2000; 75(1):6-17.

10. Chanishvili N, Chanishvili T, Tediashvili M, Barrow P A. Phages and their application against drugresistant bacteria. J Chem Technol Biotechnol. 2001; 76(7):689-99.

11. Dash M, Padhi S, Mohanty I, Panda P, Parida B. Antimicrobial resistance in pathogens causing urinary tract infections in a rural community of Odisha, India. J Family Community Med. 2013; 20(1):20-26.

12. Shakya P, Barrett P, Diwan V, Marothi Y, Shah H, Chhari N. Antibiotic resistance among Escherichia coli isolates from stool samples of children aged 3 to 14 years from Ujjain, India. BMC Infectious Diseases. 
$2013 ; 13: 477$.

13. Niranjan V, Malini A. Antimicrobial resistance pattern in Escherichia coli causing urinary tract infection among patients. Indian J Med Res. 2014; 139(6):945-948.

14. Dugal S, Purohit H. Antimicrobial susceptibility profile and detection of extended spectrum betalactamase production by gram negative uropathogens. International Journal of Pharmacy and Pharmaceutical Sciences. 2013; 5(4):434-438.

15. Jayanti Ray, Rudrajit Paul, Abhik Haldar, Sagnic Mondol. A study on antibiotic resistance pattern of Escherichia coli isolated from urine specimens in Eastern India. International Journal of Medical Science and Public Health. 2015; 4(12):1670-1674.

16. Ackermann HW. 5500 Phages examined in the electron microscope. Arch Virol. 2007; 152(2):227-43.

17. Tiwari R, Hirpurkar SD, Shakya,S. Isolation and characterization of lytic phage from natural waste material of livestock. Indian Vet. J. 2010; 87: 644-646.

18. Keivan Beheshti Maal, Abbas Soleimani Delfan, Sharareh Salmanizadeh. Isolation and identification of two novel Escherichia coli bacteriophages and their application in wastewater treatment and coliform's phage therapy. Jundishapur J Microbiol. 2015; 8(3): e14945.

19. Qin Peng, Yihui Yuan. Characterization of a newly isolated phage infecting pathogenic Escherichia coli and analysis of its mosaic structural genes. Scientific Reports. 2018; 8:8086.

20. Indira T Kudva, Srdjan Jelacic, Phillip I Tarr, Philip Youderian, Carolyn J Hovde. Biocontrol of Escherichia coli 0157 with 0157-Specific Bacteriophages. Appl Environ Microbiol. 1999; 65(9):37673773.

21. Feng YY, Ong SL, Hu JY, Tan XL, Ng WJ. Effects of $\mathrm{pH}$ and temperature on the survival of coliphages MS2 and Qb. J Ind Microbiol Biotechnolgy. 2003; 30 (9):549-552.

22. Periasamy D, Sundaram A. A novel approach for pathogen reduction in wastewater treatment. J Environ Health Sci Eng. 2013; 11(1):12.

23. Bauer AW, Kirby WMM, Sherries JC, Turck M. Antibiotic susceptibility testing by a standardized single disk method. Am J Clinical Pathol. 1996; 45(4):493-496.

24. CLSI (2006) Performance standards for antimicrobial susceptibility testing, Fifteenth Informational Supplement, CLSI document, M100-S16, vol 26-3; M7-A7, vol 26-2; M2-A9, vol 26-1. Wayne, PA, US.

25. Sambrook J, Fritsch E.F, Maniatis T. Molecular cloning: a laboratory manual, 2nd ed., Cold Spring Habor laboratory Press, Cold Spring Harbor, N.Y. 1989; 30(8):623-623. 
26. Shende RK, Hirpurkar SD, Sannat C, Rawat N, Pandey V. Isolation and characterization of bacteriophages with lytic activity against common bacterial pathogens. Veterinary World. 2017; 10(8):973-978.

27. Sambrook J, Russell DW. Molecular Cloning: A Laboratory Manual, New York: Cold Spring Harbor 2001.

28. Adams MH. Discovery of bacteriophages and methods of study of bacterial viruses. Bacteriophages. Interscience Publication, New York. 1959; 42:447-448.

29. Jordan TC, Barker LP, Bradley KW, Khaja R, Lewis MF. Isolate novel phage from the environment. NGRI Phage Resource Guide. Howard Hughes Medical Institute, 2011.

30. Kutter E. Phage host range and efficiency of plating. Methods in Molecular Biology. 2009; 501:141149.

31. Kaliniene L, Klausa V, Truncaite L. Low-temperature T4-like coliphages vB_EcoM-VR5, vB_EcoM VR7 and vB_EcoM-VR20. Arch. Virol. 2010; 155:871-880.

\section{Tables}

Table 1: Antibiotic susceptibility testing of E. coli strain against 11 antibiotics.

\begin{tabular}{|l|l|l|l|}
\hline S.No. & Antibiotics & Resistant & Susceptible \\
\hline 1. & Cefixime & + & - \\
\hline 2. & Amoxyclav & + & - \\
\hline 3. & Amikacin & + & - \\
\hline 4. & Azithromycin & - & - \\
\hline 5. & Ofloxacin & - & + \\
\hline 6. & Streptomycin & - & + \\
\hline 7. & Fusidic acid & - & + \\
\hline 8. & Norfloxacin & - & + \\
\hline 9. & Tetracycline & - & + \\
\hline 10. & Cefotaxime & + & - \\
\hline 11. & Methicillin & + & - \\
\hline
\end{tabular}

Table 2: Phage titer of sewage water sample from the plate having countable plaques (within the range of 30300) in terms of Plaque-forming units (PFU)/ml against each dilution factor. 


\begin{tabular}{|l|l|l|l|l|l|l|}
\hline S.No & $\begin{array}{l}\text { Plate } \\
\text { no. }\end{array}$ & $\begin{array}{l}\text { Plaques per } \\
\text { plate }\end{array}$ & Dilution & $\begin{array}{l}\text { Dilution } \\
\text { Factor } \\
(\mathrm{DF})\end{array}$ & $\begin{array}{l}\text { Volume of phage } \\
\text { plated (ml) }\end{array}$ & $\begin{array}{l}\text { Titer: } \\
\text { Plaque-forming units } \\
(\text { PFU) } / \mathrm{ml}\end{array}$ \\
\hline 1. & E1. & 129 & $10^{-1}$ & $10^{1}$ & $0.1 \mathrm{ml}$ & $129 \times 10^{1} / 0.1=129 \times 10^{2}$ \\
\hline 2. & E2. & 102 & $10^{-2}$ & $10^{2}$ & $0.1 \mathrm{ml}$ & $102 \times 10^{2} / 0.1=102 \times 10^{3}$ \\
\hline 3. & E3. & 66 & $10^{-3}$ & $10^{3}$ & $0.1 \mathrm{ml}$ & $66 \times 10^{3} / 0.1=66 \times 10^{4}$ \\
\hline 4. & E4. & 41 & $10^{-4}$ & $10^{4}$ & $0.1 \mathrm{ml}$ & $41 \times 10^{4} / 0.1=41 \times 10^{5}$ \\
\hline 5. & E5. & 20 & $10^{-5}$ & $10^{5}$ & $0.1 \mathrm{ml}$ & $20 \times 10^{5} / 0.1=20 \times 10^{6}$ \\
\hline 6. & E6. & 11 & $10^{-6}$ & $10^{6}$ & $0.1 \mathrm{ml}$ & $11 \times 10^{6} / 0.1=11 \times 10^{7}$ \\
\hline 7. & E7. & 0 & $10^{-7}$ & $10^{7}$ & $0.1 \mathrm{ml}$ & $0 \times 10^{7} / 0.1=0$ \\
\hline 8. & E8. & 0 & $10^{-8}$ & $10^{8}$ & $0.1 \mathrm{ml}$ & $0 \times 10^{8} / 0.1=0$ \\
\hline 9. & E9. & 0 & $10^{-9}$ & $10^{9}$ & $0.1 \mathrm{ml}$ & $0 \times 10^{9} / 0.1=0$ \\
\hline 10. & E10. & 0 & $10^{-10}$ & $10^{10}$ & $0.1 \mathrm{ml}$ & $0 \times 10^{10} / 0.1=0$ \\
\hline
\end{tabular}

Table 3: Plaque morphology of phage lysate against different dilutions.

\begin{tabular}{|c|c|c|c|c|c|c|c|c|}
\hline \multirow[t]{2}{*}{ S.No } & \multirow[t]{2}{*}{$\begin{array}{l}\text { Plate } \\
\text { No. }\end{array}$} & \multirow[t]{2}{*}{$\begin{array}{l}\text { Total no. of plaques } \\
\text { per plate }\end{array}$} & \multirow[t]{2}{*}{$\mathrm{PFU} / \mathrm{ml}$} & \multicolumn{3}{|c|}{$\begin{array}{l}\text { Morphology on the basis of } \\
\text { size }\end{array}$} & \multicolumn{2}{|c|}{$\begin{array}{l}\text { Morphology on the basis } \\
\text { of shape }\end{array}$} \\
\hline & & & & $\begin{array}{l}\text { Small } \\
(<1 \\
\mathrm{mm})\end{array}$ & $\begin{array}{l}\text { Medium (=1 } \\
\mathrm{mm})\end{array}$ & $\begin{array}{l}\text { Large } \\
(>\quad 1 \\
\mathrm{mm})\end{array}$ & Clear & Diffused \\
\hline 1. & $\mathrm{~A}$ & 129 & $129 \times 10^{2}$ & 69 & 39 & 21 & 9 & 120 \\
\hline 2. & B & 102 & $102 \times 10^{3}$ & 58 & 41 & 3 & 11 & 91 \\
\hline 3. & C & 66 & $66 \times 10^{4}$ & 45 & 11 & 10 & 34 & 32 \\
\hline 4. & $\mathrm{D}$ & 41 & $41 \times 10^{5}$ & 31 & 10 & - & 21 & 20 \\
\hline 5. & $\mathrm{E}$ & 20 & $20 \times 10^{6}$ & 9 & 10 & 1 & 18 & 2 \\
\hline 6. & $\mathrm{~F}$ & 11 & $11 \times 10^{7}$ & 11 & - & 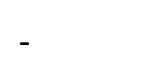 & 11 & - \\
\hline
\end{tabular}


Table 4: Phage titer calculation of pure single phage strain in terms of Plaque-forming units (PFU)/ml against each dilution factor.

\begin{tabular}{|c|c|c|c|c|c|}
\hline $\begin{array}{l}\text { Plate } \\
\text { no. }\end{array}$ & $\begin{array}{l}\text { Plaques per } \\
\text { plate }\end{array}$ & Dilution & $\begin{array}{l}\text { Dilution Factor } \\
\text { (DF) }\end{array}$ & $\begin{array}{l}\text { Volume of phage plated } \\
\text { (ml) }\end{array}$ & $\begin{array}{l}\text { Titer: } \\
\text { Plaque-forming units } \\
(\mathrm{PFU}) / \mathrm{ml}\end{array}$ \\
\hline 1. & TNTC & $10^{-1}$ & $10^{1}$ & $0.1 \mathrm{ml}$ & - \\
\hline 2. & TNTC & $10^{-2}$ & $10^{2}$ & $0.1 \mathrm{ml}$ & - \\
\hline 3. & TNTC & $10^{-3}$ & $10^{3}$ & $0.1 \mathrm{ml}$ & - \\
\hline 4. & 3760 & $10^{-4}$ & $10^{4}$ & $0.1 \mathrm{ml}$ & $3760 \times 10^{4} / 0.1=376 \times 10^{6}$ \\
\hline 5. & 1616 & $10^{-5}$ & $10^{5}$ & $0.1 \mathrm{ml}$ & $\begin{array}{ll}1616 & \mathrm{X} 10^{5} / 0.1= \\
161.6 \times 10^{7} & \end{array}$ \\
\hline 6. & 168 & $10^{-6}$ & $10^{6}$ & $0.1 \mathrm{ml}$ & $168 \times 10^{6} / 0.1=168 \times 10^{7}$ \\
\hline 7. & 16 & $10^{-7}$ & $10^{7}$ & $0.1 \mathrm{ml}$ & $16 \times 10^{7} / 0.1=16 \times 10^{8}$ \\
\hline 8. & 6 & $10^{-8}$ & $10^{8}$ & $0.1 \mathrm{ml}$ & $6 \times 10^{8} / 0.1=6 \times 10^{9}$ \\
\hline 9. & 0 & $10^{-9}$ & $10^{9}$ & $0.1 \mathrm{ml}$ & $0 \times 10^{9} / 0.1=0$ \\
\hline 10. & 0 & $10^{-10}$ & $10^{10}$ & $0.1 \mathrm{ml}$ & $0 \times 10^{10} / 0.1=0$ \\
\hline
\end{tabular}

Table 5: Pure phage stability assessment at different parameters.

\begin{tabular}{|l|l|l|l|l|l|l|l|}
\hline \multicolumn{7}{|c|}{ Pure phage stability assessment at different conditions (vaibility in \%age wrt control) } \\
\hline \multicolumn{3}{|c|}{ Temperature } & \multicolumn{5}{c|}{ pH } \\
\hline $4^{\circ} \mathrm{C}$ & $37^{\circ} \mathrm{C}$ & $50^{\circ} \mathrm{C}$ & 3 & 5 & 7 & 9 & 11 \\
\hline 100 & 100 & 99.7 & 93 & 94.5 & 100 & 80 & 2 \\
\hline
\end{tabular}

\section{Figures}




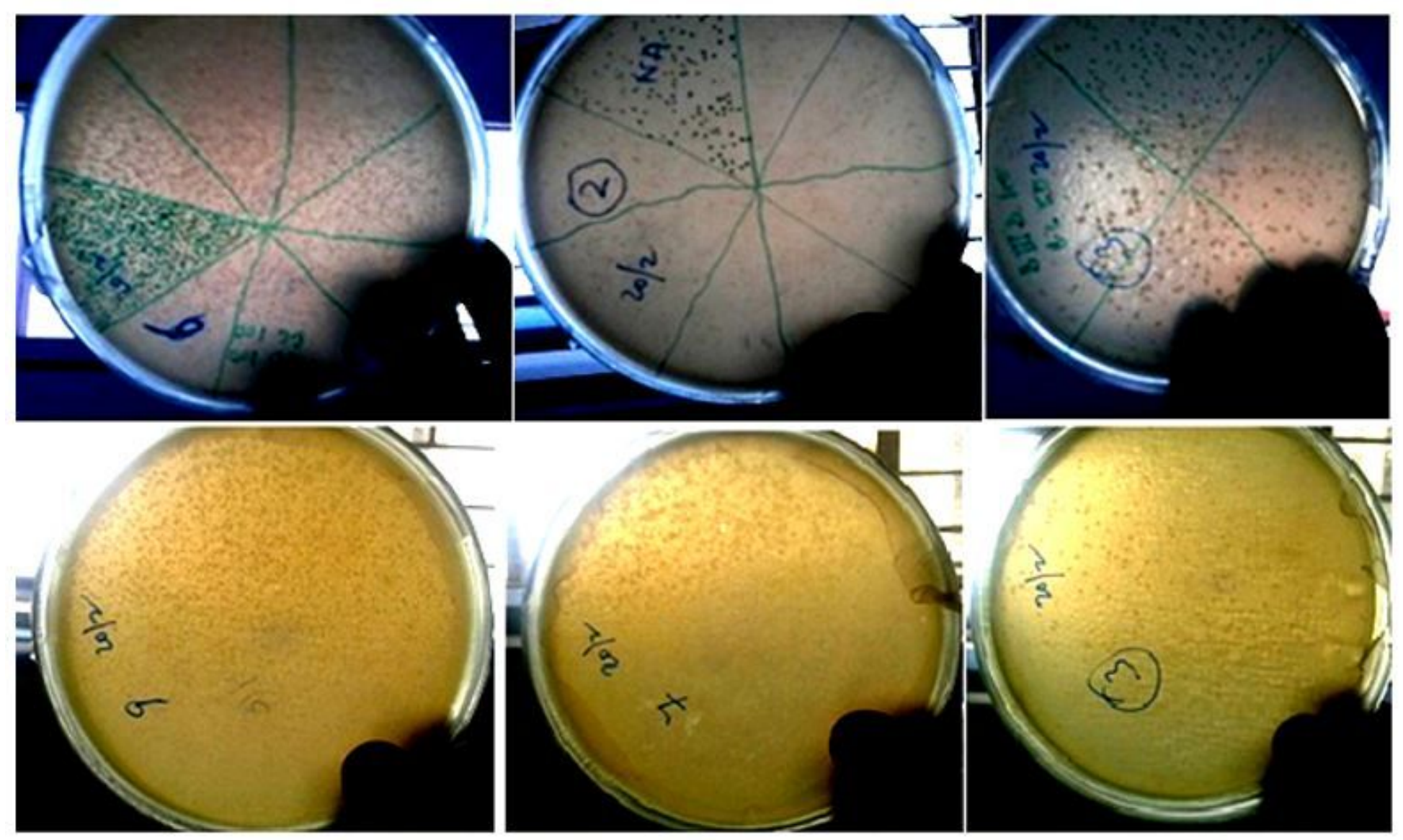

Figure 1

Plaque formation against multi-drug resistant E.coli. 


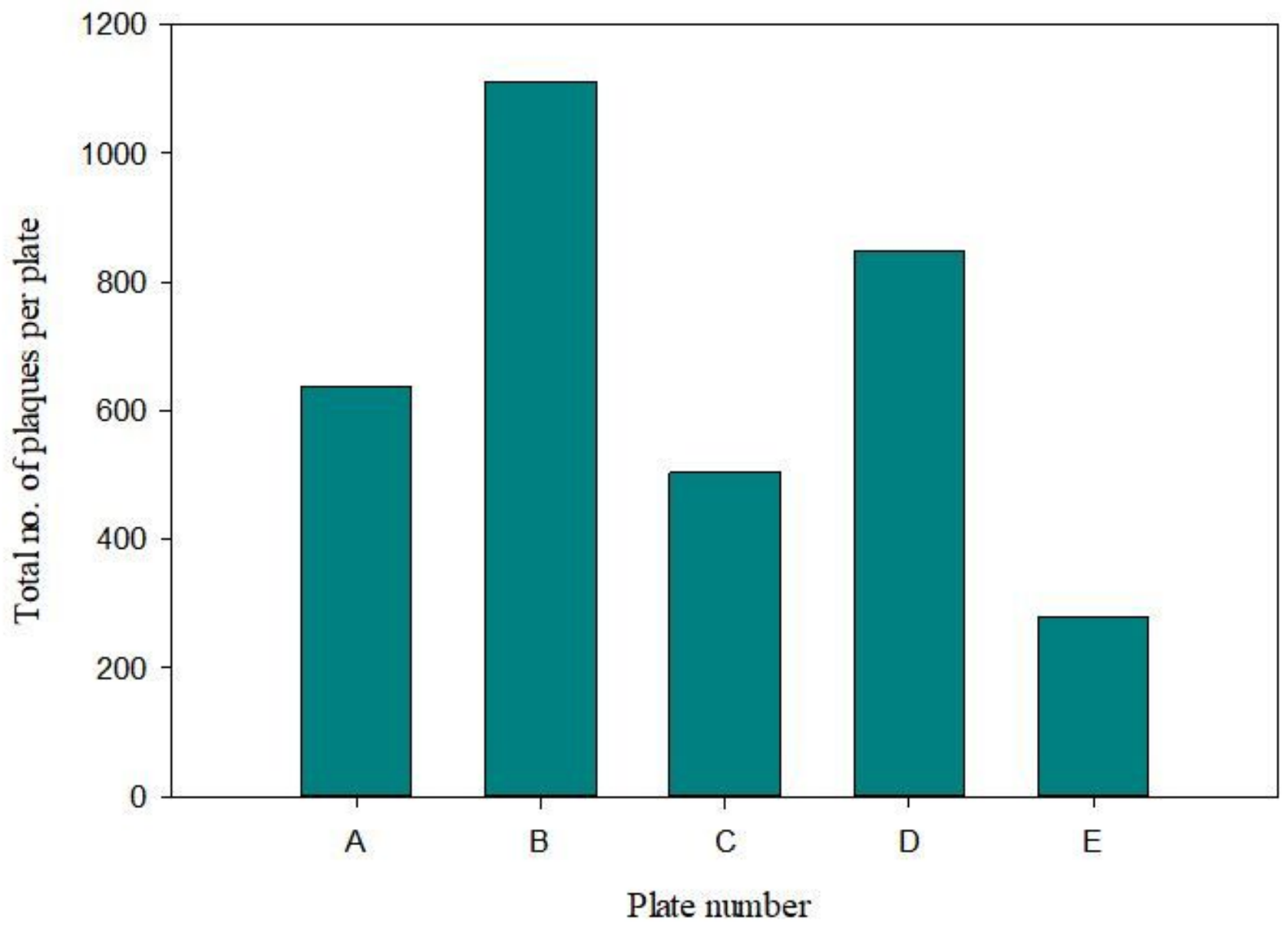

Figure 2

Total number of plaques formed in each plate

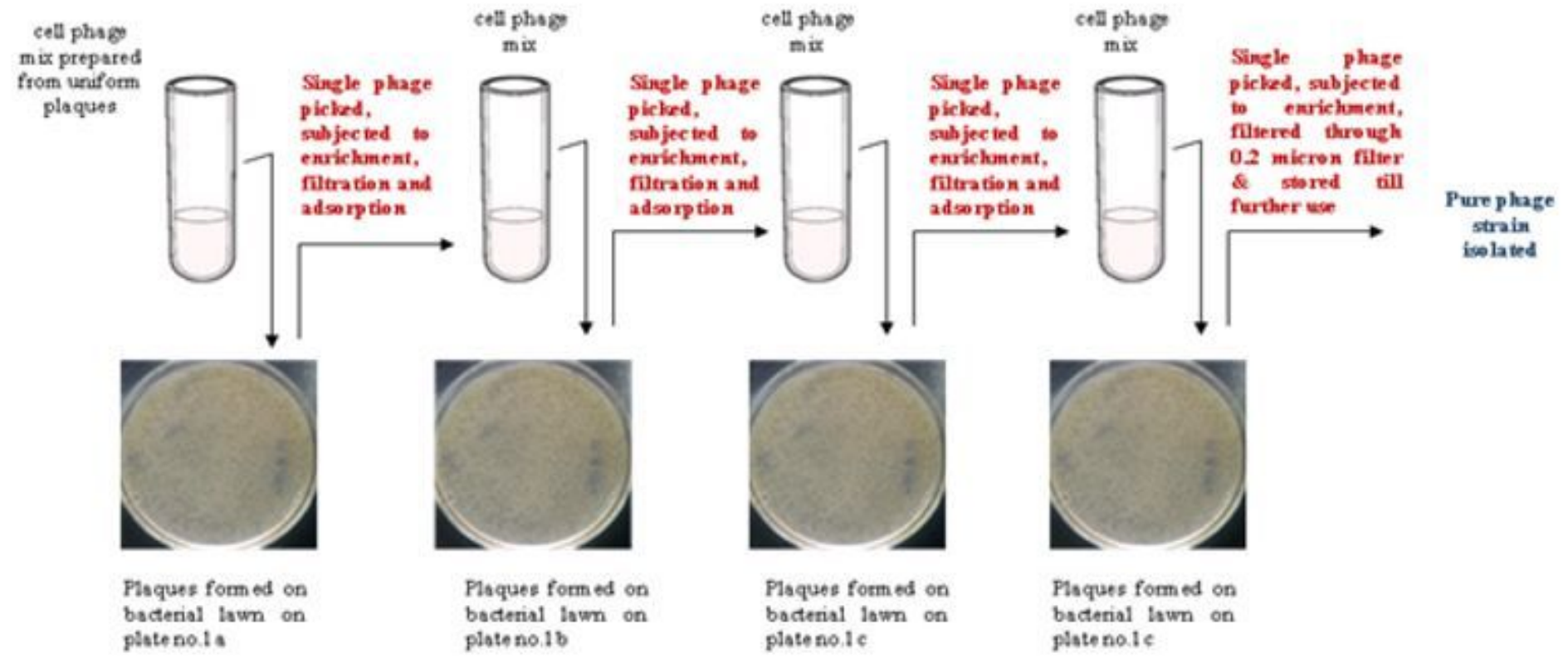

Figure 3 
Pure single phage isolation step-by-step.

Page 15/15 